\title{
Desain Modifikasi Struktur Gedung Twin Tower Universitas Negeri Sunan Ampel Surabaya dengan Menggunakan Sistem Ganda dan Balok Pratekan pada Lantai Atap
}

\author{
Wisnu Priambodo, Endah Wahyuni, dan Bambang Piscesa \\ Departemen Teknik Sipil, Fakultas Teknik Sipil, Lingkungan, dan Kebumian, \\ Institut Teknologi Sepuluh Nopember (ITS) \\ e-mail: piscesa@ce.its.ac.id
}

\begin{abstract}
Abstrak-Gedung Twin Tower Universitas negeri sunan ampel Surabaya merupakan gedung yang difungsikan sebagai rektorat yang memiliki 9 lantai ditambah lantai atap. Struktur gedung Twin Tower merupakan struktur beton bertulang biasa. Pada lantai 9 merupakan ruang serba guna sehingga tidak ada kolom ditengah ruangan. Dan pada lantai atap terdapat balok bentang panjang yang memiliki dimensi $60 \times 120 \mathrm{~cm}$. Penggunaan balok bentang panjang dengan beton bertulang biasa akan menghasilkan dimensi yang besar dan juga tulangan yang banyak. Selain itu, dalam penerapannya beton bertulang biasa dinilai kurang efektif baik dalam segi bahan maupun materialnya, sebagai langkah efektif maka dilakukan perubahan struktur pada lantai atap menggunakan sistem beton pratekan. Dalam perencanaannya, struktur Gedung Twin Tower UINSA Surabaya ini menggunakan Sistem Ganda. Sistem Ganda (dual system) adalah salah satu sistem struktur yang beban gravitasinya dipikul sepenuhnya oleh rangka utama, sedangkan beban lateralnya dipikul bersama oleh rangka utama dan dinding struktur. Rangka utama dan dinding struktur didesain sebagai Struktur Rangka Pemikul Momen Khusus (SRPMK) dan Dinding Struktur Beton Khusus (DSBK). Berdasarkan hasil analisa didapatkan dimensi balok pratekan $50 \times 75 \mathrm{~cm}$ dengan bentang $15 \mathrm{~m}$ dan tebal shearwall $350 \mathrm{~mm}$. Dari perhitungan di dapatkan Shearwall menahan beban gaya gempa arah $x \mathbf{7 3 \%}$ dan arah y $70 \%$, sedangkan rangka pemikul momen menahan beban gempa arah $x 27 \%$ dan arah y $30 \%$. Kemudian di dapat gaya pratekan awal sebesar $1300 \mathrm{KN}$ dengan jumlah tendon 1 dan berisi 12 strand. Selanjutnya di dapat kehilangan pratekan sebesar $23,4 \%$ serta prestressing partial ratio (PPR) $24,46 \%$.
\end{abstract}

Kata Kunci-Gedung Twin Tower, Beton Pratekan, Beton Bertulang, Sistem Ganda.

\section{PENDAHULUAN}

G EDUNG Twin Tower merupakan gedung Twin A Universitas negeri sunan ampel Surabaya (UINSA) terletak di JL Ahmad Yani no 117 Surabaya. Gedung ini merupakan gedung yang difungsikan sebagai rektorat yang memiliki 9 lantai ditambah lantai atap. Struktur gedung Twin Tower merupakan struktur beton bertulang biasa. Pada jurnal ini akan dilakukan modifikasi gedung rektorat pada balok lantai atap, dimana dibawah lantai atap yaitu pada lantai 9 merupakan ruang serba guna dengan tidak ada kolom di tengah ruang sehingga harus menggunakan balok bentang panjang. Pada kondisi awal balok pada lantai atap menggunakan perencanaan beton bertulang biasa sehingga memiliki dimensi balok 60 x $120 \mathrm{~cm}$. Penggunaan balok bentang panjang dengan beton bertulang biasa akan menghasilkan dimensi yang besar dan juga tulangan yang banyak. Selain itu, dalam penerapannya beton bertulang biasa dinilai kurang efektif baik dalam segi bahan maupun materialnya, sebagai langkah efektif maka dilakukan perubahan struktur pada lantai atap menggunakan sistem beton pratekan.

Surabaya yang saat ini sudah masuk kedalam kategori daerah dengan potensi gempa yang tinggi, dan memiliki jenis tanah lunak menjadikan perencanaan modifikasi gedung Twin Tower UINSA menggunakan Sistem Ganda. Sistem ganda digunakan untuk mendesain beton bertulang pada keseluruhan struktur dan penggunaan balok pratekan pada hall yang tidak membutuhkan kolom di tengah-tengah ruangan. Sehingga, ruang hall menjadi lebih nyaman dan luas dibandingkan dengan penggunaan balok non pratekan yang akan menghasilkan dimensi yang lebih besar.

Modifikasi perencanaan struktur ini dilakukan dengan menggunakan panduan tata cara perhitungan beton untuk bangunan gedung SNI 2847:2013 [1], perencanaan ketahanan gempa untuk bangunan gedung SNI 1726:2012 [2] Peta Hazard Gempa Indonesia 2010 [3] dan Peraturan Pembebanan PPIUG 1983 [4].

\section{TINJAUAN PUSTAKA}

\section{A. Sistem Ganda (Dual System)}

Sistem Ganda atau Dual System adalah salah satu sistem struktur yang beban gravitasinya dipikul sepenuhnya oleh Space Frame (Rangka), sedangkan beban lateralnya dipikul bersama oleh Space Frame dan Shear Wall (Dinding Geser/Dinding Struktur). Menurut SNI 1726-2012 pasal 7.2.5.1 menyebutkan bahwa untuk Sistem Ganda, rangka pemikul momen harus mampu menahan paling sedikit $25 \%$ gaya gempa desain. Tahanan gaya gempa total harus disediakan oleh kombinasi rangka pemikul momen dan dinding geser atau rangka bresing dengan distribusi yang proporsional terhadap kekakuannya. Karena Shear Wall dan Space Frame dalam Dual System merupakan satu kesatuan struktur maka diharapkan keduanya dapat mengalami defleksi lateral yang sama atau setidaknya Space Frame mampu mengikuti defleksi lateral yang terjadi. Shear Wall sendiri artinya adalah Dinding Geser yang terbuat dari beton 


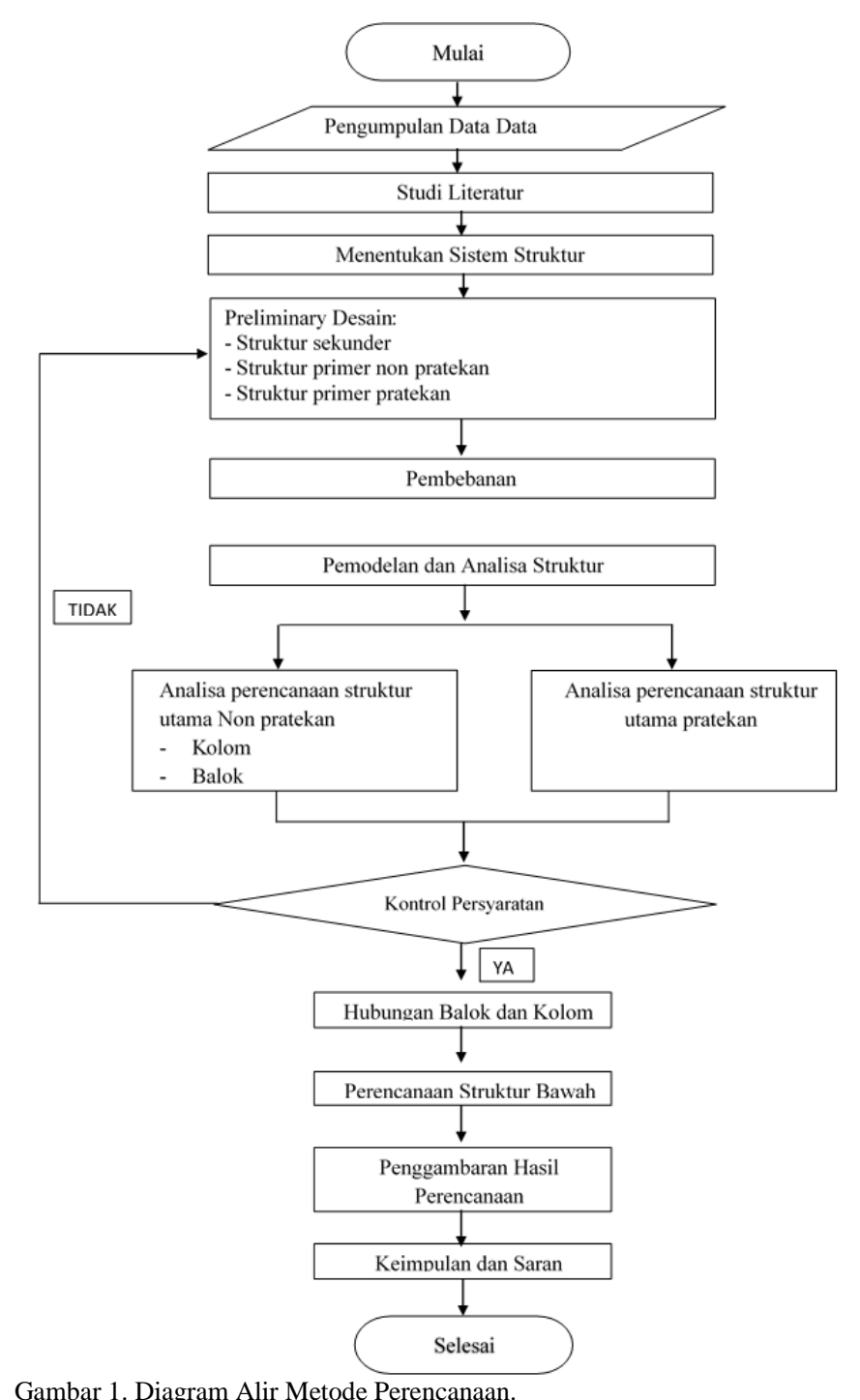

Gambar 1. Diagram Alir Metode Perencanaan.

bertulang dimana tulangan-tulangan tersebut yang akan menerima gaya lateral akibat gempa sebesar beban yang telah direncanakan [5]. Sistem Ganda pada dasarnya terdiri dari:

1. Rangka ruang memikul seluruh beban gravitasi.

2. Pemikul beban lateral berupa dinding geser atau rangka bresing (bracing) dengan rangka pemikul momen. Rangka pemikul momen harus direncanakan secara terpisah mampu memikul sekurang-kurangnya 25 persen dari seluruh beban lateral, sedangkan sisanya akan dipikul oleh dinding geser [5].

\section{B. Beton Pratekan}

Beton pratekan adalah kombinasi antara beton mutu tinggi dan baja mutu tinggi yang dikombinasikan dengan cara aktif.

Cara aktif ini dapat dicapai dengan cara menarik baja dengan menahannya ke beton, sehingga beton dalam keadaan tertekan. Beton pratekan merupakan beton yang mengalami tegangan internal dengan benar dan distribusi sedemikian rupa sehingga dapat mengimbangi tegangan yang terjadi akibat beban eksternal sampai batas tertentu. Menurut SNI 2847:2013, tendon pada beton pratekan tidak boleh sama sekali memikul beban gempa, bahkan tidak dianjurkan digunakan pada zona gempa tinggi. Tetapi jika ada gempa maka beban tersebut dipikul oleh tulangan lunak. Sedangkan menurut ACI 318-2008 Pasal. 21.5.2.5 tendon pratekan diperbolehkan menerima $25 \%$ momen positif atau negatif.

Jenis Beton pratekan dibagi menjadi dua, yaitu :

1. Beton Pratekan metode Pratarik (Pretension)

Beton pratekan metode pratarik adalah beton prategang yang dihasilkan dengan memberi tegangan awal pada tendon baja sebelum proses pengecoran [6][7].

2. Beton Pratekan metode Pascatarik (Posttension)

Merupakan beton pratekan yang dihasilkan dengan memberikan tegangan padatendon baja setelah proses pengecoran beton (dimana beton telah mengeras mencapai sebagian kekuatannya) [6][7].

\section{METODOLOGI}

\section{A. Umum}

Langkah langkah pengerjaan jurnal ini dijelaskan dalam diagram alir pada Gambar 1.

\section{B. Data-Data Perancanaan Struktur}

Pada jurnal ini terdapat data- data yang digunakan sebagai perencanaan struktur gedung yang di sajikan pada Tabel 1 . Selain itu untuk potongan dari gedung yang ditinjau dapat dilihat pada Gambar 2.

Tabel 1.

Data Bangunan

\begin{tabular}{ll}
\hline \hline Parameter & Keterangan \\
\hline Type Bangunan & Perkantoran \\
Lokasi Bangunan & Surabaya \\
Letak Bangunan & Jauh dari pantai \\
Panjang Bangunan & $34,8 \mathrm{~m}$ \\
Lebar Bangunan & $26,5 \mathrm{~m}$ \\
Tinggi Bangunan & $38 \mathrm{~m}(10$ lantai) \\
Dimensi Kolom & $0.6 \mathrm{~m}, 0.9 \mathrm{~m}$ \\
Mutu Beton (fc') & $30 \mathrm{MPa}$, dan $40 \mathrm{Mpa}$ \\
Mutu Tulangan & $400 \mathrm{MPa}$ \\
\hline \hline
\end{tabular}

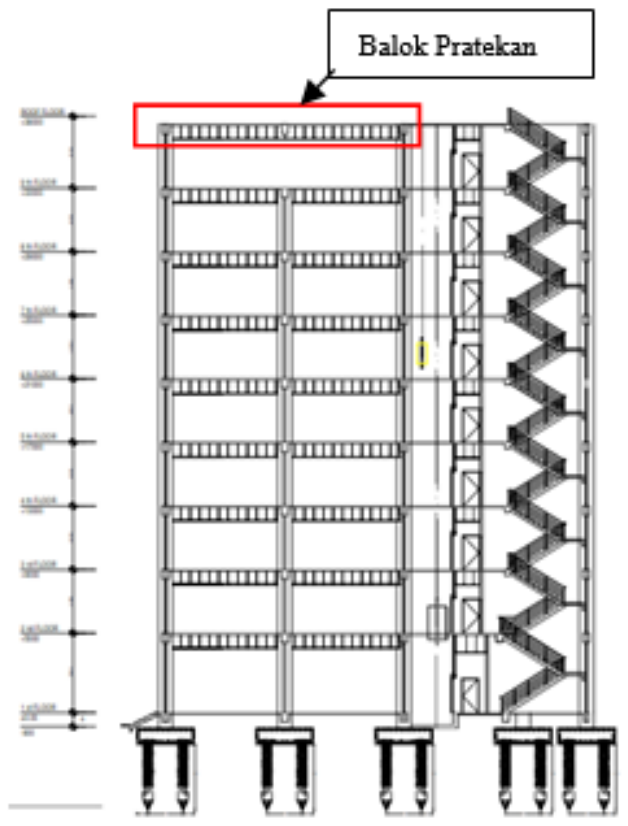

Gambar 1. Potongan gedung modifikasi. 


\section{Permodelan dan Analisis Struktur}

Analisa struktur dengan dilakukan dengan program bantu ETABS dengan ketentuan:

1. Model didefinisikan sebagai struktur open frame dimana dinding tidak dimodelkan tetapi dijadikan beban pada frame.

2. Gaya gempa dimodelkan dengan metode respons spektrum.

Untuk permodelan dari struktur yang di modifikasi dapat dilihat pada Gambar 3.

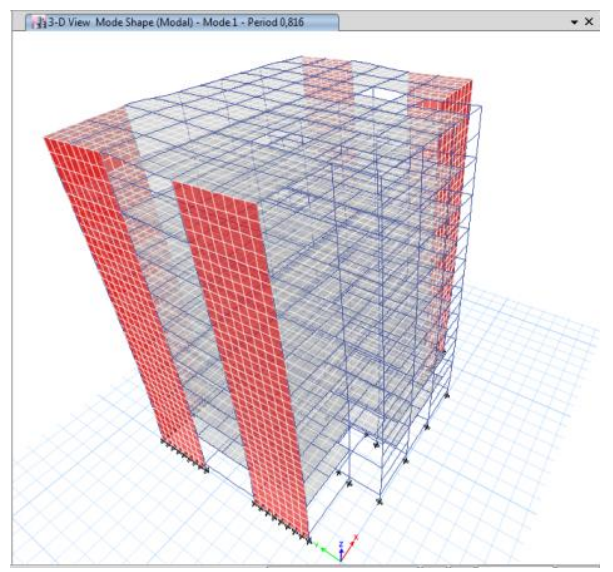

Gambar 2. Gambar permodelan.

Struktur sekunder yang dihitung adalah pelat, tangga, balok anak, dan balok lift. Sedangkan struktur utama yang dihitung adalah balok pratekan, balok induk, kolom, shearwall. Dan untuk struktur bawah yang dihitungadalah pile cap dan Tie beam serta kebutuhan pondasi tiang pancang.

\section{Kontrol Permodelan}

\section{Kontrol Periode(T)}

Nilai T (waktu getar alami struktur) dibatasi oleh waktu getar alami fundamental untuk mencegah pengunaan struktur yang terlalu fleksibel. Periode fundamental, T, tidak boleh melebihi hasil koefisien untuk batasan atas pada periode yang dihitung $(\mathrm{Cu})$ dan periode fundamental pendekatan Ta. Kontrol T yang terjadi dapat dilihat pada Tabel 2.

Tabel 2.

Nilai Periode Struktur (T) dari program ETABS

\begin{tabular}{ccccc}
\hline Case & Mode & Period & Sum UX & Sum UY \\
\hline Modal & 1 & 0,816 & 0,4847 & 0,2106 \\
Modal & 2 & 0,547 & 0,7075 & 0,6961 \\
Modal & 3 & 0,378 & 0,7078 & 0,6962 \\
Modal & 4 & 0,171 & 0,8777 & 0,7342 \\
Modal & 5 & 0,123 & 0,9152 & 0,9058 \\
Modal & 6 & 0,085 & 0,9153 & 0,9059 \\
Modal & 7 & 0,077 & 0,9631 & 0,9144 \\
Modal & 8 & 0,057 & 0,9681 & 0,9628 \\
Modal & 9 & 0,049 & 0,986 & 0,9657 \\
Modal & 10 & 0,04 & 0,986 & 0,9657 \\
Modal & 11 & 0,037 & 0,9928 & 0,9718 \\
Modal & 12 & 0,036 & 0,9944 & 0,9859 \\
\hline \hline
\end{tabular}

Kontrol periode fundamental struktur sebagai berikut :
$\mathrm{Ta} \leq \mathrm{T}$
$\leq \mathrm{Cu}$.Ta
$0,7 \mathrm{~s} \leq 0,8 \mathrm{~s} \leq 1,06 \mathrm{~s}$
$(\mathrm{OK})$

Kontrol gaya dinamis struktur digunakan untuk melihat apakah gaya gempa yang dimasukkan dengan menggunakan respon spectrum sudah sesuai dengan yang di syaratkan SNI 1726-2012 pasal 7.8.1. Hasil kontrol Geser dasar dapat dilihat pada Tabel 3.

Tabel 3.

Kontrol Akhir Gaya Geser Dasar

\begin{tabular}{|c|c|c|}
\hline Load Case/Combo & FX & FY \\
\hline & $\mathrm{kN}$ & $\mathrm{kN}$ \\
\hline Gempa x Max & 8247,214 & 8878,797 \\
\hline Gempa y Max & 6238,695 & 8150,310 \\
\hline $\begin{array}{r}=1038112,293 \\
>0,85 \mathrm{~V} \text { statik } \\
\mathrm{N}>0,85.10381\end{array}$ & $\begin{array}{l}\mathrm{kN} \\
2,293 \mathrm{kN}\end{array}$ & \\
\hline $\mathrm{N}>882395,45 \mathrm{k}$ & & $(\mathrm{OK})$ \\
\hline
\end{tabular}

$887879,72 \mathrm{kN}>882395,45 \mathrm{kN} \quad(\mathrm{OK})$

3. Kontrol Partisipasi Masa

Sesuai SNI 1726:2012 Ps 7.9.1 perhitungan respons dinamik struktur harus sedemikian rupa sehingga partisipasi massa dalam menghasilkan respon total sekurang kurangnya adalah $90 \%$. Hasil kontrol partisipasi massa dapat dilihat pada Tabel 4.

Tabel 4

Rasio Partisipasi Massa

\begin{tabular}{ccccc}
\hline \hline Case & Mode & Period & Sum UX & Sum UY \\
\hline Modal & 1 & 0,816 & 0,4847 & 0,2106 \\
Modal & 2 & 0,547 & 0,7075 & 0,6961 \\
Modal & 3 & 0,378 & 0,7078 & 0,6962 \\
Modal & 4 & 0,171 & 0,8777 & 0,7342 \\
Modal & 5 & 0,123 & 0,9152 & 0,9058 \\
Modal & 6 & 0,085 & 0,9153 & 0,9059 \\
Modal & 7 & 0,077 & 0,9631 & 0,9144 \\
Modal & 8 & 0,057 & 0,9681 & 0,9628 \\
Modal & 9 & 0,049 & 0,986 & 0,9657 \\
Modal & 10 & 0,04 & 0,986 & 0,9657 \\
Modal & 11 & 0,037 & 0,9928 & 0,9718 \\
Modal & 12 & 0,036 & 0,9944 & 0,9859 \\
\hline \hline
\end{tabular}

\section{Kontrol Dual System}

Untuk sistem ganda, rangka pemikul momen harus mampu menahan paling sedikit 25 persen gaya gempa desain. Tahanan gaya gempa total harus disediakan oleh kombinasi rangka pemikul momen dan dinding geser atau rangka bresing, dengan distribusi yang proporsional terhadap kekakuannya [5]. Hasil distribusi beban Sistem rangka dan Dinding Geser dapat dilihat pada Tabel 5 .

Tabel 5.

Distribusi Beban Sistem Rangka dan Dinding Geser

\begin{tabular}{ccccccccc}
\hline \hline Pemikul & \multicolumn{3}{c}{ Gempa X } & \multicolumn{3}{c}{ Gempa Y } \\
\cline { 2 - 9 } Gaya & \multicolumn{2}{c}{ Fx } & \multicolumn{2}{c}{ Fy } & \multicolumn{2}{c}{ Fx } & Fy \\
Geser & $\mathrm{KN}$ & $\%$ & $\mathrm{KN}$ & $\%$ & $\mathrm{KN}$ & $\%$ & $\mathrm{KN}$ & $\%$ \\
\hline Shear Wall & 6945,28 & 72 & 7416,75 & 75 & 5354,10 & 71 & 6766,25 & 73 \\
SRPM & 2714,02 & 28 & 2465,45 & 25 & 2232,10 & 29 & 2456,53 & 27 \\
Total & 9659,31 & 100 & 9882,50 & 100 & 7586,21 & 100 & 9222,79 & 100 \\
\hline \hline
\end{tabular}

\section{HASIL PERENCANAAN}

\section{A. Perencanaan Struktur Sekunder}

Struktur sekunder yang dilakukan perhitungan adalah pelat, tangga, balok bordes, balok lift dan balok anak. 1. Pelat

2. Kontrol Gaya Geser Dasar (Base Shear) 
Perencanaan pelat menggunakan data fc' $30 \mathrm{MPa}$, fy 240 Mpa. Untuk hasil perencanaan pelat lantai dapat dilihat pada Tabel 6.

Tabel 6.

Rekapitulasi Penulangan Pelat Lantai.

\begin{tabular}{|c|c|c|c|c|c|c|}
\hline \multirow[t]{2}{*}{ Tipe Pelat } & \multicolumn{2}{|c|}{ Dimensi } & \multicolumn{2}{|c|}{ Penulangan Tump } & \multicolumn{2}{|c|}{ Penulangan Lap } \\
\hline & $\mathrm{p}(\mathrm{m})$ & $1(\mathrm{~m})$ & $\mathrm{X}$ & $\mathrm{Y}$ & $\mathrm{X}$ & $\mathrm{Y}$ \\
\hline P1 & 4 & 3,75 & Ǿ10-150 & Ǿ10-150 & Ǿ10-150 & Ǿ10-150 \\
\hline P2 & 3,75 & 3,2 & Ǿ10-150 & Ǿ10-150 & Ǿ10-150 & Ǿ10-150 \\
\hline P3 & 3,75 & 3 & Ǿ10-150 & Ǿ10-150 & Ǿ10-150 & Ǿ10-150 \\
\hline P4 & 4 & 3 & Ǿ10-150 & Ǿ10-150 & Ǿ10-150 & Ǿ10-150 \\
\hline P5 & 3,2 & 2,25 & Ǿ10-150 & Ǿ10-150 & Ǿ10-150 & Ǿ10-150 \\
\hline P6 & 3,2 & 2,75 & Ǿ10-150 & Ǿ10-150 & Ǿ10-150 & Ǿ10-150 \\
\hline
\end{tabular}

2. Tangga

Perencanaan tangga menggunakan data fc' $30 \mathrm{MPa}$, fy 240

Mpa. Untuk hasil perencanaan pelat tangga dapat dilihat pada Tabel 7.

Tabel 7.

Rekapitulasi Penulangan Pelat Tangga

\begin{tabular}{|c|c|c|c|}
\hline Type Tangga & Jenis Pelat & Penulangan Lentur & Penulangan Susut \\
\hline \multirow[b]{2}{*}{ Tangga 1} & Tangga & Ǿ16-100 & Ǿ10-250 \\
\hline & Bordes & Ǿ16-100 & Ǿ10-250 \\
\hline Tangga 2 & Tangga & Ǿ16-100 & Ǿ10-250 \\
\hline
\end{tabular}

3. Balok Bordes, Balok Lift, dan Balok Anak

Perencanaan tangg menggunakan data fc'30 MPa, fy 400 Mpa dan fyv $240 \mathrm{Mpa}$. Untuk hasil perencanaan balok bordes dan balok anak dapat dilihat pada Tabel 8 dan Tabel 9.

Tabel 8.

Rekapitulasi Penulangan Balok Bordes

\begin{tabular}{ccccccc}
\hline \hline Type & \multicolumn{3}{c}{ Penulangan Lentur } & \multicolumn{2}{c}{ Penulangan Geser } \\
\cline { 2 - 5 } Balok & \multicolumn{2}{c}{ Tumpuan } & \multicolumn{2}{c}{ Lapangan } & \multirow{2}{*}{ Tumpuan } & \multirow{2}{*}{ Lapangan } \\
\cline { 2 - 5 } Bordes & Tarik & Tekan & Tarik & Tekan & & \\
\hline Bordes 1 & 2D16 & 2D16 & 2D16 & 2D16 & 2 Ǿ10-120 & 2 Ǿ10 - 120 \\
Bordes 2 & 2D16 & 2D16 & 2D16 & 2D16 & 2 Ǿ10-120 & 2 Ǿ10-120 \\
\hline \hline
\end{tabular}

Tabel 9.

\begin{tabular}{|c|c|c|c|c|c|c|}
\hline \\
\hline \multirow{3}{*}{$\begin{array}{c}\text { Type } \\
\text { Balok } \\
\text { Anak }\end{array}$} & \multicolumn{4}{|c|}{ Penulangan Lentur } & \multicolumn{2}{|c|}{ Penulangan Geser } \\
\hline & \multicolumn{2}{|c|}{ Tumpuan } & \multicolumn{2}{|c|}{ Lapangan } & \multirow[t]{2}{*}{ Tumpuan } & \multirow[t]{2}{*}{ Lapangan } \\
\hline & Tarik & Tekan & Tarik & Tekan & & \\
\hline BA 1 & 2D16 & 2D16 & 2D16 & 2D16 & $2 \varnothing ́ 10-150$ & $2 \varnothing \dot{10-150}$ \\
\hline BA 2 & 3D16 & 2D16 & 2D16 & 2D16 & $2 \varnothing ́ 10-150$ & $2 \varnothing \dot{10}-150$ \\
\hline
\end{tabular}

\section{B. Perencanaan Struktur Primer}

\section{Balok Pratekan}

Metode konsep dasar untuk mendesain elemen beton prategang, tegangan serat beton dihitung dari gaya luar yang bekerja di beton akibat pemberian prategang longitudinal dan beban luar transversal [6]. Untuk penampang balok pratekan dapat dilihat pada Gambar 4.

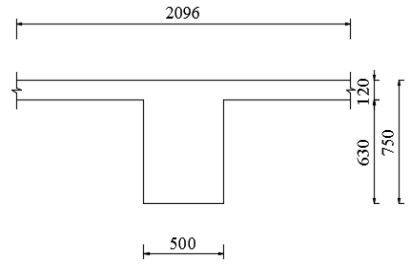

Gambar 3. Penampang balok pratekan.

Data balok Pratekan:

- Dimensi Balok : 500/750 mm

- Bentang Balok : $15000 \mathrm{~mm}$

- Mutu Beton (Fc') : $40 \mathrm{Mpa}$
- Mutu Tendon :

○ Jenis Tendon : AS 4672

- Nominal Diameter $\quad: 15,2 \mathrm{~mm}$

○ Luas Kawat : $143,3 \mathrm{~mm} 2$

- Minimum Breaking Load : $250 \mathrm{KN}$

Di dapat hasil : Fo $\quad=1300 \mathrm{kN}$

Jumlah Tendon $\quad=1$ buah

Jumlah Strand $\quad=8$ buah

Hasil kehilangan gaya pratekan dapat dilihat pada Tabel 10.

Tabel 10.

Kehilangan Pratekan

\begin{tabular}{|c|c|c|}
\hline \multirow[b]{2}{*}{ Level tegangan tiap tahap } & Tegangan baja & Persen \\
\hline & Mpa & $\%$ \\
\hline \multicolumn{3}{|l|}{ Tegangan efektif } \\
\hline Sesudah penarikan $0,7 \mathrm{fpu}$ & 1221,214236 & $100 \%$ \\
\hline \multicolumn{3}{|l|}{ Kehilangan langsung } \\
\hline 1 kehilangan perpedekan elastis & 0 & 0 \\
\hline 2 Kehilangan angker slip & 51,31 & $4,2 \%$ \\
\hline 3 Kehilangan wobble effect & 60,16 & $4,9 \%$ \\
\hline Kehilangan Kekangan kolom & 38,46 & $2,907 \%$ \\
\hline Total Kehilangan Langsung & 149,93 & $12,035 \%$ \\
\hline \multicolumn{3}{|l|}{ Kehilangan tak langsung } \\
\hline 1 Kehilangan rangkak & 7,30 & $0,6 \%$ \\
\hline 2 Kehilangan susut & 35,25 & $2,9 \%$ \\
\hline \multirow{3}{*}{$\begin{array}{l}3 \text { Kehilangan relaksasi baj } \\
\text { Total Kehilangan Tak La } \\
\text { Total kehilangan }\end{array}$} & 96,08 & $7,9 \%$ \\
\hline & 138,63 & $11,4 \%$ \\
\hline & 288,55 & $23,4 \%$ \\
\hline Tegangan efektif & 932,66 & $76,6 \%$ \\
\hline
\end{tabular}

Kontrol Lendutan:

$\Delta_{\mathrm{ijin}} \quad=\mathrm{L} / 480 \quad=15000 \mathrm{~mm} / 480$

Lendutan total saat beban layan adalah:

$\Delta \mathrm{l}_{\mathrm{tr}} \quad=\Delta \mathrm{l}_{\mathrm{po}}+\Delta \mathrm{l}_{\mathrm{qo}}+\Delta \mathrm{l}_{\mathrm{me}}$

$=-15,95 \mathrm{~mm}+0 \mathrm{~mm}+44,05 \mathrm{~mm}$

$=30,15 \mathrm{~mm}$ (Kebawah)

Kontrol: $\quad \Delta \mathrm{l}_{\mathrm{tr}} \leq \Delta_{\mathrm{ijin}}$

Keterangan:

$30,15 \mathrm{~mm} \leq 31,3 \mathrm{~mm} \quad$ (Memenuhi)

$\Delta \mathrm{l}_{\mathrm{po}} \quad=$ Lendutan Akibat Tekanan Tendon

$\Delta \mathrm{l}_{\mathrm{qo}} \quad=$ Lendutan Akibat Beban Kerja

$\Delta \mathrm{l}_{\mathrm{me}} \quad=$ Lendutan Akibat Eksentrisitas

Hasil perhitungan tulangan lunak balok pratekan dapat dilihat pada Tabel 11. Kemudian untuk penampang tulangan balok pratekan dapat dilihat pada Gambar 5.

Tabel 11.

Penulangan Lunak

\begin{tabular}{cccccccc}
\hline \hline Jenis & \multicolumn{4}{c}{ Penulangan Lentur } & \multicolumn{2}{c}{ Penulangan Geser } & \\
\cline { 2 - 5 } $\begin{array}{c}\text { Balok } \\
\text { Pratekan }\end{array}$ & \multicolumn{2}{c}{ Tumpuan } & \multicolumn{2}{c}{ Lapangan } & \multirow{2}{*}{ Tumpuan } & \multirow{2}{*}{ Lapangan } & \\
\cline { 2 - 5 } & Tarik & Tekan & Tarik & Tekan & & \\
\hline BP1 & 6D29 & 3D29 & 5D29 & 3D29 & 4 Ǿ13-100 & 2 Ǿ13-200 & 2D19 \\
\hline BP2 & 6D29 & 3D29 & 5D29 & 3D29 & 4 Ǿ13-100 & 2 Ǿ13-200 & 2D19 \\
\hline \hline
\end{tabular}

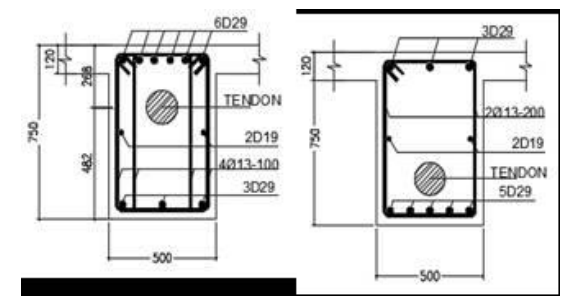

Gambar 4. Tulangan Tumpuan dan Lapangan Balok Pratekan 1 Prestress Partial Ratio (PPR). 
$\mathrm{PPR}=\frac{M n p}{M n} \quad=24,46 \%$

Mnp = Kapasitas Momen Nominal Balok Pratekan

Mn = Total Kapasitas Momen Nominal

2. Balok Induk (BI)

Perencanaan balok induk menggunakan data data sebagai berikut:

- Dimensi Balok : 400/600 mm

- Bentang Balok : $7500 \mathrm{~mm}$

- Mutu Beton (Fc') : $30 \mathrm{Mpa}$

- Mutu Baja (Fy) : 400 Mpa

Hasil perencanaan balok induk disajikan pada Tabel 12 dan penampang penulangan balok induk lantai dapat dilihat pada Gambar 6.

Tabel 12.

Penulangan Balok Induk

\begin{tabular}{cccccccc}
\hline \hline \multirow{2}{*}{ Jenis Balok } & \multicolumn{3}{c}{ Penulangan Lentur } & \multicolumn{2}{c}{ Penulangan Geser } & \multirow{2}{*}{ Torsi } \\
\cline { 2 - 5 } & \multicolumn{2}{c}{ Tumpuan } & Lapangan & \multirow{2}{*}{ Tumpuan } & Lapangan & \\
\cline { 2 - 6 } & Tarik & Tekan & Tarik & Tekan & & & \\
\hline BI Lantai & 8D22 & 4D22 & 4D22 & 2D22 & 4 Ǿ13-100 & 2 Ǿ13-150 & 4D19 \\
BI Atap & 7D22 & 4D22 & 3D22 & 2D22 & 2 Ǿ13-125 & 2 Ǿ13-150 & 2D16 \\
\hline \hline
\end{tabular}
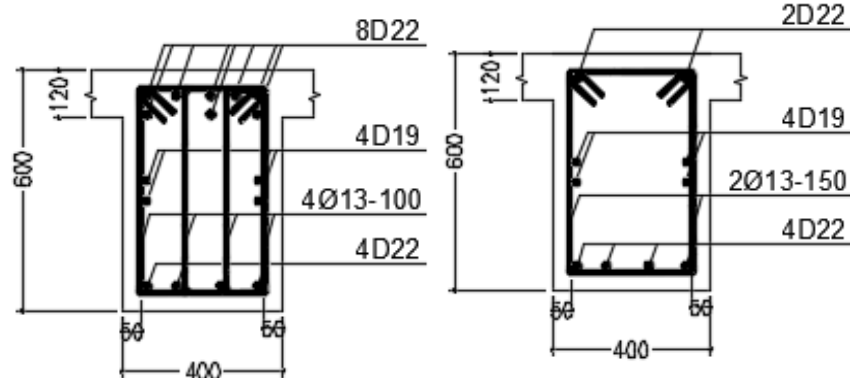

Gambar 5. Potongan Penulangan Balok Induk.

\section{Kolom}

Persyaratan untuk kuat lentur kolom harus memenuhi ketentuan kolom kuat balok lemah [8].

Data Kolom:

- Dimensi Kolom : 600/900 mm

- Bentang Kolom : 5000, $4000 \mathrm{~mm}$

- Mutu Beton (Fc') : $30 \mathrm{Mpa}$

- Muru Baja (Fy) : 400 Mpa

Hasil perencanaan kolom disajikan pada Tabel 13 dan penampang tulangan kolom dapat dilihat pada Gambar 7.

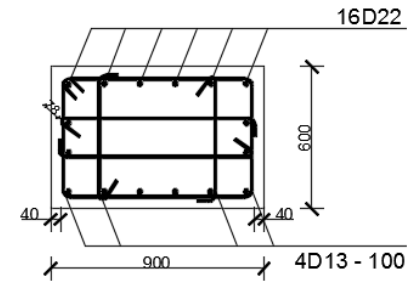

Gambar 6. Penulangan kolom.

Tabel 13.

Penulangan Kolom

\begin{tabular}{cccc}
\hline \hline \multirow{2}{*}{ Jenis kolom } & \multirow{2}{*}{ Penulangan Lentur } & \multicolumn{2}{c}{ Penulangan Geser } \\
\cline { 3 - 4 } & & Sendi Plastis & Luar Sendi Plastis \\
\hline K1 & 16D22 & 4 Ǿ13 - 100 & 4 Ǿ13 - 150 \\
K2 & 16D22 & 4 Ǿ13 - 100 & 4 Ǿ13 - 150 \\
\hline \hline
\end{tabular}

4. Dinding geser (Shearwall)

Perencanaan dinding ikut memikul beban yang bekerja pada struktur dengan memikul beban horizontal.

Data Shearwall:

$\begin{array}{ll}\text { - Tebal SW } & : 350 \mathrm{~mm} \\ \text { - Tinggi SW } & : 5000,4000 \mathrm{~mm} \\ \text { - Tipe SW } & : \text { Tipe Lurus dan Siku } \\ \text { - Mutu Beton }\left(\mathrm{Fc}^{\prime}\right) & : 30 \mathrm{Mpa} \\ \text { - Muru Baja (Fy) } & : 400 \mathrm{Mpa}\end{array}$

Hasil perencanaan dinding geser disajikan pada Tabel 14.

Tabel 14.

Penulangan Dinding Geser

\begin{tabular}{|c|c|c|c|c|}
\hline $\begin{array}{c}\text { Jenis } \\
\text { Shearwall }\end{array}$ & Bentuk & n Utama & $\begin{array}{c}\text { Tulangan } \\
\text { Transversal }\end{array}$ & $\begin{array}{l}\text { Tulangan } \\
\text { Pembatas }\end{array}$ \\
\hline \multirow[b]{2}{*}{ SW 1} & \multirow{2}{*}{ Siku L } & Segn & $2 \varnothing \dot{13}-250$ & Ǿ13 - 150 \\
\hline & & Segmen 2: 64 D22 - 200 & $2 \varnothing ́ 13-250$ & Ǿ13 - 150 \\
\hline SW2 & Lurus & 89 D22 - 200 & $2 \emptyset \dot{13}-250$ & Ǿ13 - 150 \\
\hline
\end{tabular}

5. Pondasi

Daya dukung tiang pada tanah pondasi umumnya diperoleh dari jumlah daya dukung terpusat tiang dan tahanan geser pada dinding tiang [9].

Data Pondasi:

- Dimensi Pile Cap Type 1 : 3040 x 3040 mm

- Tebal Pile Cap : $1000 \mathrm{~mm}$

- Tiang Pancang : Tipe Bulat D $600 \mathrm{~mm}$

- Kedalaman Tiang $\quad: 20 \mathrm{~m}$

- Mutu Beton (Fc') : $30 \mathrm{Mpa}$

- Mutu Baja (Fy) : $400 \mathrm{Mpa}$

Poer dikontrol terhadap geser pons yang terjadi. Untuk penulangan lentur, poer dianalisis sebagai balok kantilever dengan perletakan jepit pada kolom. Dan beban yang bekerja adalah beban terpusat di tiang kolom yang menyebabkan reaksi pada tanah dan berat sendiri poer [10]. Hasil analisa perhitungan poer pondasi disajikan pada Tabel 15.

$$
\text { Tabel } 15 .
$$

Hasil Perhitungan Pondasi

\begin{tabular}{cccccccc}
\hline \hline Tipe & \multicolumn{3}{c}{ Dimensi $(\mathrm{m})$} & \multirow{2}{*}{ Jumlah Tiang } & \multirow{2}{*}{$\begin{array}{c}\text { Kedalaman } \\
\text { Tiang }(\mathrm{m})\end{array}$} & \multicolumn{2}{c}{ Penulangan Pile Cap } \\
\cline { 2 - 3 } Pilecap & $\mathrm{p}$ & $\mathrm{l}$ & $\mathrm{t}$ & & Arah x & Arah y \\
\hline P1 & 3,04 & 3,04 & 1 & 4 & 20 & D29 - 150 & D22 - 150 \\
P2 & 11,7 & 5 & 1 & 21 & 24 & D29-150 & D22 - 150 \\
\hline \hline
\end{tabular}

\section{KESIMPULAN}

\section{A. Kesimpulan}

Dari hasil perhitungan-perhitungan dapatkan hasil analisa sebagai berikut :

1. Perencanaan desain modifikasi struktur gedung Twin Tower dengan menggunakan dual sistem dan penggunaan balok pratekan dengan bentang $15 \mathrm{~m}$ pada lantai atap.

2. Hasil Perencanaan Gedung Twin Tower UINSA Surabaya sebagai berikut :

Struktur Sekunder :

- Balok anak $\quad: 25 / 40 \mathrm{~cm}$

- Tebal Pelat Lantai : $12 \mathrm{~cm}$

- Tebal Pelat Tangga : $20 \mathrm{~cm}$

- Balok Bordes $\quad: 25 / 40 \mathrm{~cm}$

- Balok lift $\quad: 40 / 60 \mathrm{~cm}$

Struktur Utama :

- Balok Pratekan : :50/75

- Balok Induk $\quad: 40 / 60 \mathrm{~cm}$

- Kolom :60/90 cm. 
- Tebal Shearwall $\quad: 350 \mathrm{~mm}$

3. Dari hasil perencanaan desain didapatkan distribusi beban lateral yang dipikul oleh sistem rangka dan dinding geser struktur utama gedung Twin Tower adalah sebagai berikut:

- Untuk beban gempa arah X, beban lateral mampu dipikul oleh struktur SRPM sebesar $27 \%$ dan struktur Dinding Geser sebesar $73 \%$.

- Untuk beban gempa arah Y, beban lateral mampu dipikul oleh struktur SRPM sebesar $30 \%$ dan Struktur Dinding Geser sebesar 70\%.

4. Didapatkan hasil desain balok pratekan sepanjang $15 \mathrm{~m}$ pada lantai atap didapat gaya pratekan awal sebesar 1300 KN dengan kehilangan pratekan sebesar 23,4\%.

5. Hasil kontribusi tendon terhadap kemampuan menerima beban pada balok pratekan sebesar PPR $=24,46 \%$.

\section{B. Saran}

Saran yang mungkin dapat membantu dalam hal perencanaan struktur Twin Tower UINSA Surabaya adalah sebagai berikut:

Untuk pratekan balok yang menerus dengan balok induk biasa maka dilakukan jeking pada balok pratekan dilakukan pada satu sisi saja, sisi lainnya dipasang angkur mati. Hal ini untuk mempermudah analisa dan pelaksanaan.

\section{DAFTAR PUSTAKA}

[1] SNI-2847-2013, Persyaratan Beton Struktural Untuk Bangunan Gedung (SNI 2847:2013). Jakarta: Badan Standardisasi Nasional, 2013.

[2] Badan Standardisasi Nasional, "SNI 1726-2012: Tata Cara Perencanaan Ketahanan Gempa untuk Bangunan Gedung," Jakarta, 2012.

[3] Kementerian Pekerjaan Umum, "Peta Hazzard Gempa Indonesia 2010 Sebagai Acuan Dasar Perencanaan dan Perancangan Infrastruktur Tahan Gempa," Jakarta, 2010.

[4] Direktorat Penyelidikan Masalah Bangunan, "Peraturan Pembebanan Indonesia Untuk Gedung 1983,” Bandung, 1983.

[5] K. Klana, M. Irmawan, and E. Wahyuni, "Modifikasi Perencanaan Struktur Gedung Ibis Styles Hotel Tanah Abang Jakarta Pusat dengan Metode Beton Pracetak," J. Tek. ITS, 2017.

[6] E. G. Nawy, Beton Prategang: Suatu Pendekatan Mendasar, 3rd ed. Jakarta: Erlangga, 2001.

[7] Soetoyo, "Konstruksi Beton Pratekan," 2015. [Online]. Available: https://dokumen.tips/dokuments/diktat-beton-prategang.html.

[8] I. Imran and F. Hendrik, Perencanaan Lanjut Struktur Beton Bertulang. Bandung: ITB, 2014

[9] I. Sosarodarsono and K. Nakazawa, Mekanika Tanah dan Teknik Pondasi. Jakarta: Pradnya Paramita, 1983.

[10] I. Budiono, E. Wahyuni, and Isdarmanu., "Perbandingan Berat Material Baja pada Perencanaan Struktur Baja Sistem Rangka Pengaku Eksentris (SRPE) dengan Sistem Staggered Trus Frames (STF) pada Apartemen Purimas Surabaya," J. Tek. ITS, vol. 6, no. 2, pp. D217-D223, 2017. 